\title{
Genetic and Environmental Variation of First Pod Height in Soybean [Glycine max (L.) Merr.]
}

\author{
Beom-Kyu Kang ${ }^{1}$, Hyun-Tae Kim ${ }^{1}$, Man-Soo Choi ${ }^{1}$, Seong-Chul Koo ${ }^{1}$, Jeong-Hyun Seo ${ }^{1}$, Hong-Sik Kim ${ }^{1}$, \\ Sang-Ouk Shin ${ }^{1}$, Hong-Tae Yun ${ }^{1}$, In-Seok Oh${ }^{1}$, Krishnanand P. Kulkami ${ }^{2}$, Jeong-Dong Lee ${ }^{2 *}$ \\ ${ }^{1}$ National Institute of Crop Science, RDA, Miryang 50424, Korea \\ ${ }^{2}$ School of Applied Biosciences, Kyungpook National University, Daegu 41566, Korea
}

\begin{abstract}
First pod height (FPH) is an agronomic trait for the mechanical harvesting of soybeans with combines. The seed loss could be minimized, if the FPH is higher than the height of the cutter bar in combines. Hence, developing soybeans with high FPH has become one of important breeding goals in current crop improvement programs. The objective of this study was to evaluate genetic and environmental variation of FPH in soybean and to analyze the effect of ratio of FPH to plant height (PH) on seed yield. Four genotypes were evaluated across six different environments to analyze environmental variation of agronomic traits including FPH. Three $\mathrm{F}_{2}$ populations were evaluated to analyze genetic variation and relationship between the ratio of FPH to PH and seed yield. The main effects of planting distance, genotype and seeding date were significant for FPH, but FPH is affected more by genetic factors than by environmental factors. The mean heritability value of FPH was $66 \%$ across three $\mathrm{F}_{2}$ populations. Seed yield was found to reduce with increase in the FPH/PH ratio. In conclusion, genetic factors have effect more than environments to the variation of FPH. While FPH is higher than cutting height, the smaller ratio can minimize seed yield decrease.
\end{abstract}

Keywords Soybean, First pod height, Yield, Mechanical harvest

\section{INTRODUCTION}

Harvesting is one of the most laborious operations in crop production (Ramteke et al. 2012). Mechanized harvesting offers a reliable and cost effective option to the farmers thereby help agriculture to remain competitive (Thompson and Blank 2000). The combine harvesters are widely used to harvest the field crops including soybean [Glycine $\max (\mathrm{L}$.$) Merr.]. Although harvesting soybeans$ with combine has an advantage of reducing the labor and production cost, but it induces seed losses. Charles et al. (1993) described six major reasons for losses during harvesting; those were pre-harvest loss (naturally lodging and shattering before harvest), shatter loss (pods are shattered by machinery shock at combine header), stubble loss (stems are cut above the lower pods and those remain on stubble), non-cutting loss (lodged plants remain on the ground below the combine cutter), cylinder loss (pods are not threshed in combine due to the high moisture and incorrect cylinder-concave settings) and separation loss (seeds pass out of the combine without storage). While the cylinder loss and separation loss could be minimized by controlling concave-setting. The development of shattering and lodging resistant soybean cultivars may help to reduce pre-harvest losses, shatter losses and non-cutting losses. Very often, the pods that are missed by the cutter bars are left on the stubble and hence not gathered into the combine. Such losses are mostly reduced by using a flexible cutter bar. Previous studies have showed that 2.5 and $2.6 \mathrm{~cm}$ increase of cutter bar caused yield loss of $94.1 \mathrm{~kg} / \mathrm{ha}$ and 27

Received February 8, 2017; Revised February 11, 2017; Accepted February 12, 2017; Published March 1, 2017

*Corresponding author Jeong-Dong Lee, jdlee@knu.ac.kr, Tel: +82-53-950-5709, Fax: +82-53-958-6880 
$\mathrm{kg} / \mathrm{ha}$, respectively (Martin and Wilcox 1973; Kowalczuk 1999). However, lowering the cutter bar may induce mechanical damage by influx with soil substances such as stones in the field. These studies imply that adjusting the cutter bar height is important and developing the soybean cultivar with higher first pod height (FPH) is also important.

Compared to the other agronomic traits, FPH have received little attention of the breeders. Nevertheless, several researchers have analyzed the genetic and environmental variation among soybean genotypes and studied the correlation of FPH with other important traits. The genetic effects of FPH are estimated by determining the broad sense heritability. Martin and Wilcox (1973) evaluated three $F_{2}$ populations for $\mathrm{FPH}$ variation to estimate the genetic effects of $F_{2}$ plants and observed heritability estimates of 0.62 . Similarly, Costa et al. (2008) evaluated $57 \mathrm{~F}_{2}$ plants and $\mathrm{F}_{3}$ lines derived from six populations and estimated heritability value, which was found to be 0.63 . Since the heritability is an indicator for genetic effects of the trait in a population or among family means (Holland and Nyquist 2003), such heritability estimates may help in early-stage phenotypic selection (Costa et al. 2008).

FPH is positively correlated with plant height, but negatively correlated with number of pods, number of seeds per plant, number of seeds per pod and seed weight (Oz et al. 2009). In an another study, Ramteke et al. (2012) reported that plant height, number of nods and stem diameter are positively correlated with each other. However, Ghodrati et al. (2013) noted that FPH was found to be negatively correlated with the seed yield, which may have been due to the high ratio of FPH to plant height (FPH/PH) and may have decreased the number of pods. Hence, more studies are needed to estimate the effects of variation in $\mathrm{FPH} / \mathrm{PH}$ on the actual seed yield, in order to develop an ideal soybean plant type. The objective of this study was to assess the genetic and environmental variation for the $\mathrm{FPH}$ and to understand the effect of $\mathrm{FPH} / \mathrm{PH}$ ratio on seed yield per plant in three $F_{2}$ populations. Additionally, broad-sense heritability was determined to understand the extent of FPH variation due to the genetic effects in the populations used. Environmental variation of FPH and correlation between FPH and agronomic traits in different seeding date and planting distance were also evaluated among the four genotypes.

\section{MATERIALS AND METHODS}

\section{Plant materials and evaluation of FPH}

Four genotypes, 'Uram' (Ko et al. 2016), 'Seonpung' (Lee et al. 2015), 'Tawon' (Lee et al. 2015), and 'Milyang 255' (Somyeong/Hannam) were selected to evaluate variation of FPH in different seeding date and planting distance. Uram, Seonpung, and Tawon are commercial cultivars whereas Milyang 255 was a breeding line. FPH of Uram and Seonpung was 19 and $18 \mathrm{~cm}$, respectively, whereas that of Tawon and Milyang 255 was found to be 7 cm (Table 1).

The experiment was conducted in Daegu experiment station, Rural Development Administration (RDA) (Dalseong, 35 $54^{\prime} 18^{\prime \prime} \mathrm{N}, 128^{\circ} 26^{\prime} 42^{\prime}$ 'E, Republic of Korea) in 2014. The experiments were designed in a split plot

Table 1. Agronomic traits of four genotypes, Uram, Seonpung, Tawon and Milyang 255 evaluated in regional yield trials conducted across eight regions in Korea for 3 years (2011-2013).

\begin{tabular}{lcccccccc}
\hline \hline \multirow{2}{*}{ Genotypes } & \multicolumn{10}{c}{ Agronomic traits } \\
\cline { 2 - 9 } & $\begin{array}{c}\text { Flowering date } \\
\text { (month day) }\end{array}$ & $\begin{array}{c}\text { Maturity date } \\
\text { (month day) }\end{array}$ & $\begin{array}{c}\text { Plant height } \\
(\mathrm{cm})\end{array}$ & $\begin{array}{c}\text { First pod height } \\
(\mathrm{cm})\end{array}$ & $\begin{array}{c}\text { Number of } \\
\text { nodes }\end{array}$ & $\begin{array}{c}\text { Number of } \\
\text { branches }\end{array}$ & $\begin{array}{c}\text { Number of } \\
\text { pods }\end{array}$ & $\begin{array}{c}100-\text { seed } \\
\text { weight }(\mathrm{g})\end{array}$ \\
\hline Uram & Aug. 1 & Oct. 9 & $79 \mathrm{a})$ & $19 \mathrm{a}$ & $14 \mathrm{~b}$ & $3.1 \mathrm{a}$ & $47 \mathrm{~b}$ & $25.8 \mathrm{a}$ \\
Seonpung & Aug. 5 & Oct. 19 & $67 \mathrm{~b}$ & $18 \mathrm{a}$ & $16 \mathrm{a}$ & $3.0 \mathrm{a}$ & $43 \mathrm{~b}$ & $25.9 \mathrm{a}$ \\
Tawon & July 21 & Sep. 29 & $51 \mathrm{c}$ & $7 \mathrm{~b}$ & $13 \mathrm{c}$ & $2.7 \mathrm{a}$ & $69 \mathrm{a}$ & $9.7 \mathrm{~b}$ \\
Milyang 255 & July 27 & Oct. 9 & $44 \mathrm{c}$ & $7 \mathrm{~b}$ & $13 \mathrm{bc}$ & $3.1 \mathrm{a}$ & $71 \mathrm{a}$ & $9.4 \mathrm{~b}$ \\
\hline
\end{tabular}

\footnotetext{
${ }^{\mathrm{z})}$ Means followed by the same letter within columns are not significantly different according to DMRT at 0.05 level.
} 
design with two replications in each seeding date. Main plots had three planting distances $(7.5,15$, and $30 \mathrm{~cm})$ and sub plots had four soybean genotypes. The plantings were made in 29th May and 27th June 2014. Plots of each genotype were planted in four-row plots $2 \mathrm{~m}$ long with spacing of $60 \mathrm{~cm}$ between rows, and hills within rows were spaced at $15 \mathrm{~cm}$ intervals with two seedlings per hill. The plants were phenotyped at R6 stage (Fehr et al. 1971) for agronomic traits such as plant height $(\mathrm{cm}), \mathrm{FPH}(\mathrm{cm})$, number of nodes, number of branches, number of pods and stem diameter $(\mathrm{mm})$. Plant height was measured as the length of the stem from the ground up to the top node. FPH was measured as the length of the stem from the ground up to the bottom of the first pod over cotyledon node. All the nodes on main stem, the branches including more than two nodes and all the pods on a plant except the empty ones were counted. Also, most thin parts of the stem between cotyledon node and unifoliate node were measured by calipers.

\section{Estimating the genetic variation of FPH}

Four soybean genotypes, a cultivar Uram and 'Chamol' (Lee et al. 2015), a breeding line 'Milyang 257' (Holl/Shingi) and a land race 'IT143195', were used to develop the segregating populations. The FPH of Uram, Chamol, Milyang 257, and IT143195 was 19, 10, 25, and $30 \mathrm{~cm}$, respectively. Four soybean genotypes were crossed in 2012 in the following combinations to develop three different segregating populations: Uram $\times$ Chamol (Pop I; $n=704)$, Uram $\times$ Milyang $257($ Pop II; $n=679)$ and IT143195 $\times$ Uram (Pop III; $n=538$ ). The parents and $F_{2}$ populations were grown at Daegu experiment station, RDA (Dalseong, $35^{\circ} 54^{\prime} 18^{\prime \prime} \mathrm{N}, 128^{\circ} 26^{\prime} 42^{\prime \prime} \mathrm{E}$, Republic of Korea). Planting was made with two seeds per hill on 19th June 2014 and thinning was carried out at V4 stage (Fehr et al. 1971) to keep one plant per hill. The plot was $4 \mathrm{~m}$ long with row spacing of $60 \mathrm{~cm}$ and hill spacing of $15 \mathrm{~cm}$, and every plot was mulched with black vinyl. All the individuals from three $F_{2}$ populations were phenotyped for plant height and FPH at R6 stage (Fehr et al. 1971). To evaluate yield components by the ratio of FPH to plant height (FPH/PH), Pop I and Pop II populations were categorized seven levels, with 5\% difference in $\mathrm{FPH} / \mathrm{PH}$. Fifteen to twenty plants were sampled randomly. The selected plants were phenotyped for number of pods, 100 -seed weight, and seed yield.

\section{Statistical analysis}

The trait data were used for the analysis of variance (ANOVA) of seeding date, planting distance and interactions, and for the analysis of correlation coefficient. The ANOVA was performed using PROC GLM of SAS (SAS 9.2). The data were analyzed in a split plot design with two seeding dates. The differences among mean values were determined using Least Significant Difference at $P \leq 0.05$ or Duncan's multiple range test at $P \leq 0.05$. R version 3.0.2 was used to draw or calculate distribution, skewness, kurtosis in $\mathrm{F}_{2}$ population and the correlation coefficient of the traits. Coefficient of variation $(\mathrm{CV})$ was used as a parameter to compare the stability of genotypes within treatments. Broad-sense heritability for FPH in the $\mathrm{F}_{2}$ populations was calculated as per the equation given by Mahmud and Kramer (1951).

$$
\begin{aligned}
& H=\frac{V_{G}}{V_{P}} \\
& V_{p}=V_{G}+V_{E} \\
& H=\frac{\sigma_{F_{2}}^{2}-\sqrt{\sigma_{P_{1}}^{2} \times \sigma_{P_{2}}^{2}}}{\sigma_{F_{2}}^{2}}
\end{aligned}
$$

Where $H$ is broad-sense heritability, $V_{G}$ is a genetic variance, $V_{P}$ is a phenotypic variance, $V_{E}$ is an environmental variance, $\sigma_{F_{2}}^{2}$ is a variance of $\mathrm{F}_{2}$ population, $\sigma_{P_{1}}^{2}$ is a variance of maternal parent, $\sigma_{P_{2}}^{2}$ is a variance of paternal parent.

\section{RESULTS}

\section{Analysis of variance of four soybean genotypes for the agronomic traits}

The combined ANOVA indicated that planting distance (D), genotype (G) were significant for plant height, FPH, number of nodes, number of branches, number of pods and stem thickness. Seeding date (S) was also significant for all the traits except number of branches. Seeding date an effect 
on FPH and interaction between genotype and seeding date was also detected (Table 2 and 3). Early seeding date showed significantly higher FPH than late seeding date, however not all the genotypes showed significant decrease at late seeding date. FPH in Seonpung significantly decreased at late seeding date but the other genotypes were not significantly changed. Genotype was significantly interacted with seeding date and planting distance for plant height, number of nodes, and number of pods, but not for the number of branches (Table 2).

The FPH was decreased by increasing the planting distance. Mean values for FPH in planting distance 15,
17.5 , and $30 \mathrm{~cm}$ were $16.1,15.3$, and $13.4 \mathrm{~cm}$, respectively (Table 3). Furthermore, the results show that the four genotypes responded differently by planting distance. FPH did not differ significantly in all the 4 genotypes planted in 7.5 and $15 \mathrm{~cm}$ distances; however the genotypes except Uram planted in $30 \mathrm{~cm}$ distance showed significant reduction in FPH.

The mean value of FPH for Uram, Seonpung, Tawon, and Milyang 255 were $21.1,19.5,8.1$, and $11.1 \mathrm{~cm}$, respectively (Table 3 ). CV of four genotypes in planting distance and seeding date was different. CV for planting distance of Uram, Seonpung, Tawon and Milyang 255 was

Table 2. Mean square value and degree of freedom for analysis of environmental variation for plant height, first pod height, number of nodes, number of branches, number of pods and stem thickness for four soybean genotypes grown in three planting distances and two seeding date in Daegu experiment station at 2014.

\begin{tabular}{lcrccccc}
\hline \hline \multicolumn{1}{c}{ Source } & $\mathrm{df}^{\mathrm{z})}$ & Plant height & $\begin{array}{c}\text { First pod } \\
\text { height }\end{array}$ & $\begin{array}{c}\text { Number of } \\
\text { nodes }\end{array}$ & $\begin{array}{c}\text { Number of } \\
\text { branches }\end{array}$ & $\begin{array}{c}\text { Number of } \\
\text { pods }\end{array}$ & $\begin{array}{c}\text { Stem thickness } \\
\text { the }\end{array}$ \\
\hline Seeding date (S) & 1 & $23,166.3^{* * *}$ & $280.1^{* * *}$ & $406.1^{* * *}$ & 4.3 & $27,592.9^{* * *}$ & $390.3^{* * *}$ \\
Block (B) & 1 & $547.3^{* * *}$ & 7.3 & $15.1^{* * *}$ & $5.3^{*}$ & $1462.5^{*}$ & 0.4 \\
Block (in seeding) & 1 & $3894.0^{* * *}$ & $130.7^{*}$ & 2.0 & 3.3 & 1188.3 & $25.2^{* * *}$ \\
Distance (D) & 2 & $2553.3^{* * *}$ & $181.9^{* * *}$ & $3.9^{*}$ & $107.0^{* * *}$ & $73,923.2^{* * *}$ & $105.6^{* * *}$ \\
$\mathrm{D} \times \mathrm{S}$ & 2 & $113.6^{*}$ & $123.2^{* * *}$ & 2.3 & 3.6 & 571.2 & 1.7 \\
Genotype (G) & 3 & $18,647.8^{* * *}$ & $2,880.4^{* * *}$ & $174.8^{* * *}$ & $21.8^{* * *}$ & $46,918.1^{* * *}$ & $32.6^{* * *}$ \\
$\mathrm{G} \times \mathrm{S}$ & 3 & $479.8^{* * *}$ & $73.3^{*}$ & $7.9^{* * *}$ & 0.5 & $2,394.3^{* * *}$ & 0.6 \\
$\mathrm{D} \times \mathrm{G}$ & 6 & $163.2^{* * *}$ & 14.9 & $4.9^{* * *}$ & 2.3 & $3,664.2^{* * *}$ & $2.5^{*}$ \\
$\mathrm{D} \times \mathrm{G} \times \mathrm{S}$ & 6 & $169.7^{* * *}$ & 34.3 & 1.9 & 1.7 & 614.2 & 1.3 \\
\hline
\end{tabular}

$*, * *$, and $* * *$ stand for significantly different at $0.5,0.01$, and 0.001 level, respectively.

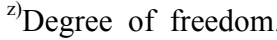

Table 3. Evaluation of first pod height and coefficient of variation in different planting distance and seeding date.

\begin{tabular}{|c|c|c|c|c|c|}
\hline \multirow{2}{*}{\multicolumn{2}{|c|}{ Treatments }} & \multicolumn{4}{|c|}{ First pod height $(\mathrm{cm})$} \\
\hline & & \multirow{2}{*}{$\begin{array}{c}\text { Uram } \\
21.0\end{array}$} & \multirow{2}{*}{$\begin{array}{c}\text { Seonpung } \\
21.2\end{array}$} & \multirow{2}{*}{$\begin{array}{c}\text { Tawon } \\
9.1\end{array}$} & \multirow{2}{*}{$\frac{\text { Milyang } 255}{13.0}$} \\
\hline Planting distance $(\mathrm{cm})$ & 7.5 & & & & \\
\hline & 15 & 22.3 & 19.2 & 8.6 & 11.1 \\
\hline & 30 & 19.8 & 18.0 & 6.4 & 9.3 \\
\hline & $\mathrm{CV}(\%)$ & 6 & 8 & 18 & 16 \\
\hline & $\mathrm{LSD}_{0.05}$ & 3.2 & 2.9 & 1.3 & 2.7 \\
\hline \multirow[t]{4}{*}{ Seeding date } & May 292014 & 21.7 & 21.9 & 8.1 & 11.9 \\
\hline & June 272014 & 20.4 & 17.1 & 8.0 & 10.4 \\
\hline & $\mathrm{CV}(\%)$ & 4 & 18 & 1 & 10 \\
\hline & $\mathrm{LSD}_{0.05}$ & 2.6 & 2.4 & 1.1 & 2.2 \\
\hline $\mathrm{CV}(\%)^{z)}$ & & 27 & 29 & 39 & 45 \\
\hline Mean ${ }^{\text {y) }}$ & & 21.1 & 19.5 & 8.1 & 11.1 \\
\hline
\end{tabular}

${ }^{\mathrm{z})} \mathrm{CV}(\%)$ was calculated across planting distance and seeding date.

${ }^{\mathrm{y})}$ Mean FPH calculated across planting distance and seeding date. 
$6,8,18$, and $16 \%$, respectively. Uram was less affected by planting distance compared to other three genotypes. CV for seeding date of Uram, Seonpung, Tawon, and Milyang 255 were $4,18,1$, and $10 \%$, respectively and Tawon was found to be less affected by seeding date. The CVs in all six environments by three planting distances and two seeding dates for Uram, Seonpung, Tawon, and Milyang 255 were $27,29,39$, and $45 \%$, respectively. This result suggests that Uram is the most stable genotype across the seeding date and planting distance.

\section{Phenotypic distribution, heritability and correlation coefficient analysis for $F P H$ in $F_{2}$ populations}

Phenotypic values, standard deviation (SD), CV, skewness, and kurtosis of FPH in three $\mathrm{F}_{2}$ populations for FPH are given in Table 4, and the frequency distribution are shown in Fig. 1. FPH of all the three populations showed transgressive segregation, suggesting the quantitative behavior of the trait. The range of FPH for Pop I, Pop II, and Pop III was 1-37, 4-50, and 4-67 cm, respectively. Mean values with SD were $14.7 \pm 6.2,24.0 \pm 6.1$, and $25.6 \pm 9.1$ $\mathrm{cm}$, and CV values were 42.1, 25.5, and 35.6\% for Pop I, Pop II, and Pop III, respectively. The skewness of Pop I, Pop II, and Pop III was $0.41,0.58$, and 0.92 , respectively and distributions were right-skewed. The kurtosis of Pop I, II, and III was $0.01,1.44$, and 1.88 and those distributions were all positive and had sharper peak with fatter tails than a normal distribution.

The range of plant height for Pop I, Pop II, and Pop III was 19-105, 30-150, and 25-200 cm, respectively. Mean values with SD of plant height for Pop I, Pop II, and Pop III were $62.9 \pm 17.6,92.6 \pm 13.4$, and $108.0 \pm 23.9 \mathrm{~cm}$,

Table 4. Mean with standard deviation (SD), range, coefficient variance (CV), skewness, kurtosis, and heritability of plant height and first pod height of three cross combinations in three $F_{2}$ populations.

\begin{tabular}{|c|c|c|c|c|c|c|c|c|c|c|c|c|c|}
\hline \multirow{2}{*}{\multicolumn{2}{|c|}{ Cross combination }} & \multicolumn{6}{|c|}{ Plant height $(\mathrm{cm})$} & \multicolumn{6}{|c|}{ First pod height $(\mathrm{cm})$} \\
\hline & & Mean \pm SD & Range & $\begin{array}{l}\mathrm{CV} \\
(\%)\end{array}$ & Skewness & Kurtosis & $\begin{array}{c}\text { Heritability } \\
(\%)^{\mathrm{z})}\end{array}$ & Mean \pm SD & Range & $\begin{array}{l}\mathrm{CV} \\
(\%)\end{array}$ & Skewness & Kurtosis & $\begin{array}{c}\text { Heritability } \\
(\%)^{z)}\end{array}$ \\
\hline \multirow{3}{*}{$\begin{array}{l}\text { Pop I } \\
(\text { Uram } \times \\
\text { Chamol) }\end{array}$} & $\mathrm{P} 1 \quad(\mathrm{n}=22)$ & $83.4 \pm 9.0$ & $72-120$ & 10.8 & -0.81 & 1.24 & \multirow{3}{*}{90} & $17.5 \pm 4.8$ & $12-35$ & 27.6 & 2.11 & 6.66 & \multirow{3}{*}{51} \\
\hline & $\mathrm{P} 2(\mathrm{n}=24)$ & $43.7 \pm 3.6$ & $37-52$ & 8.2 & 0.35 & 0.02 & & $10.6 \pm 3.9$ & 3-18 & 15.1 & 0.29 & -0.43 & \\
\hline & $\mathrm{F}_{2}(\mathrm{n}=704)$ & $62.9 \pm 17.6$ & $19-105$ & 27.9 & -0.28 & -0.54 & & $14.7 \pm 6.2$ & $1-37$ & 42.1 & 0.41 & 0.01 & \\
\hline \multirow{3}{*}{$\begin{array}{l}\text { Pop II } \\
(\text { Uram } \times \\
\text { Milyang 257) }\end{array}$} & $\mathrm{P} 1(\mathrm{n}=25)$ & $91.7 \pm 4.2$ & $81-98$ & 4.6 & -0.63 & -0.08 & \multirow{3}{*}{82} & $21.6 \pm 2.2$ & $16-25$ & 10.3 & -0.49 & 0.17 & \multirow{3}{*}{79} \\
\hline & $\mathrm{P} 2(\mathrm{n}=23)$ & $88.0 \pm 7.9$ & $71-100$ & 9.0 & -0.87 & -0.03 & & $24.6 \pm 4.2$ & $15-33$ & 17.1 & -0.12 & 0.32 & \\
\hline & $\mathrm{F}_{2}(\mathrm{n}=679)$ & $92.6 \pm 13.4$ & $30-150$ & 14.5 & -0.22 & 1.65 & & $24.1 \pm 6.1$ & $4-50$ & 25.5 & 0.58 & 1.44 & \\
\hline \multirow{3}{*}{$\begin{array}{l}\text { Pop III } \\
(\text { IT143195 } \times \\
\text { Uram) }\end{array}$} & P1 $(\mathrm{n}=11)$ & $126.8 \pm 18.6$ & $81-162$ & 14.7 & -0.79 & 3.42 & \multirow{3}{*}{73} & $30.9 \pm 5.4$ & $20-38$ & 17.4 & -0.48 & -0.30 & \multirow{3}{*}{67} \\
\hline & $\mathrm{P} 2(\mathrm{n}=25)$ & $86.4 \pm 8.4$ & $63-101$ & 9.7 & -0.78 & 0.88 & & $20.2 \pm 5.1$ & $10-31$ & 25.2 & -0.17 & -0.06 & \\
\hline & $\mathrm{F}_{2}(\mathrm{n}=538)$ & $108.0 \pm 23.9$ & $25-200$ & 22.1 & 0.39 & 1.44 & & $25.6 \pm 9.1$ & 4-67 & 35.6 & 0.92 & 1.88 & \\
\hline Mean & & & & & & & 81 & & & & & & 66 \\
\hline
\end{tabular}

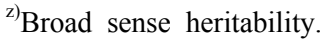

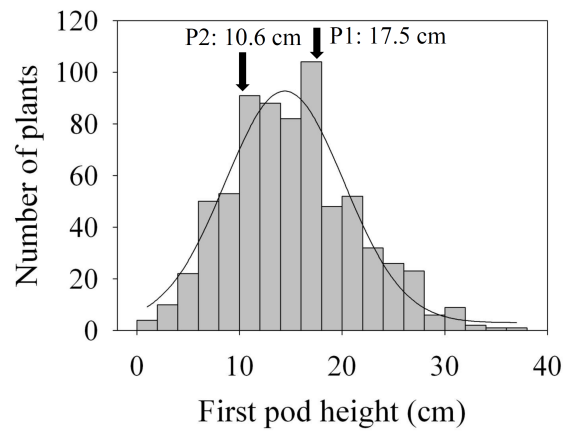

Pop I

P1 : Uram

P2 : Chamol

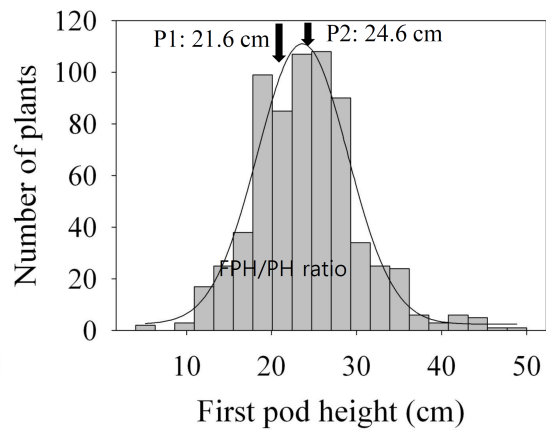

Pop II

P1 : Uram

P2 : Milyang 257

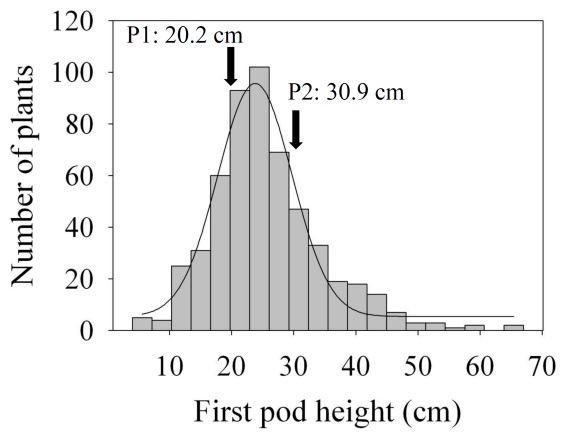

Pop III

P1 : IT143195

P2 : Uram

Fig. 1. Frequency distribution for first pod height in three $F_{2}$ populations evaluated in Daegu experiment station 2014 . P1, maternal parent; P2, paternal parent. 
respectively. CV values for Pop I, Pop II, and Pop III were $27.9,14.5$, and $22.1 \%$, respectively. The skewness of Pop I, Pop II, and Pop III for plant height was $-0.28,-0.22$, and 0.39, respectively. The kurtosis of Pop I, Pop II, and Pop III for plant height was $-0.54,1.65$, and 1.44, respectively. The skewness and kurtosis of plant height were tended to left skewed and wider peak compared with FPH.

Broad-sense heritability estimates for FPH and plant height in three populations are shown in Table 4.

Table 5. Correlation coefficient among agronomic traits of four genotypes evaluated in two seeding date and three planting distance.

\begin{tabular}{|c|c|c|c|c|c|c|}
\hline Agronomic traits & Plant height & $\begin{array}{l}\text { First pod } \\
\text { height }\end{array}$ & $\begin{array}{c}\text { Number of } \\
\text { nodes }\end{array}$ & $\begin{array}{c}\text { Number of } \\
\text { branches }\end{array}$ & $\begin{array}{c}\text { Numberof } \\
\text { pods }\end{array}$ & $\begin{array}{c}\text { Stem } \\
\text { thickness }\end{array}$ \\
\hline Plant height & 1 & & & & & \\
\hline FPH & $0.61 * * *$ & 1 & & & & \\
\hline No. of nodes & $0.66^{* * *}$ & $0.49 * * *$ & 1 & & & \\
\hline No. of branches & $-0.06^{\mathrm{NS}}$ & $-0.18^{* * *}$ & $0.25 * * *$ & 1 & & \\
\hline No. of pods & $-0.29 * * *$ & $-0.47 * * *$ & $0.06^{\mathrm{NS}}$ & $0.58 * * *$ & 1 & \\
\hline Stem thickness & $0.45^{* * *}$ & $0.17 * * *$ & $0.67 * * *$ & $0.47 * * *$ & $0.43 * * *$ & 1 \\
\hline
\end{tabular}

NS and *** stands for none significant at 0.05 level and significant different at 0.001 level, respectively.

Table 6. Mean value of seed yield per plant, number of pods, one hundred weight, first pod height and plant height by the ratio of FPH to plant height which calculated from randomly sampled plants in two $\mathrm{F}_{2}$ populations in Daegu experiment station in 2014.

\begin{tabular}{|c|c|c|c|c|c|c|c|c|}
\hline \multirow{2}{*}{$\begin{array}{c}\text { Cross } \\
\text { combination }\end{array}$} & \multirow{2}{*}{ Traits $^{\mathrm{z})}$} & \multicolumn{7}{|c|}{ Ratio of first pod height to plant height } \\
\hline & & $0.05-0.10$ & $0.11-0.15$ & $0.16-0.20$ & $0.21-0.25$ & $0.26-0.30$ & $0.31-0.35$ & $0.36-0.40$ \\
\hline \multirow{5}{*}{$\begin{array}{l}\text { Pop I } \\
\text { (Uram } \times \\
\text { Chamol) }\end{array}$} & YP (g/plant) & $\begin{array}{l}32.0 \mathrm{a}^{\mathrm{y})} \\
(8-50)^{\mathrm{x})}\end{array}$ & $\begin{array}{l}26.3 \mathrm{ab} \\
(2-62)\end{array}$ & $\begin{array}{l}21.7 \mathrm{bc} \\
(8-54)\end{array}$ & $\begin{array}{l}21.0 \mathrm{bc} \\
(6-58)\end{array}$ & $\begin{array}{c}23.3 \mathrm{abc} \\
(4-56)\end{array}$ & $\begin{array}{l}15.5 c \\
(4-32)\end{array}$ & $\begin{array}{l}15.2 \mathrm{c} \\
(4-28)\end{array}$ \\
\hline & NP & $\begin{array}{c}79 a \\
(25-148)\end{array}$ & $\begin{array}{c}59 \mathrm{abc} \\
(10-130)\end{array}$ & $\begin{array}{c}49 b c \\
(21-111)\end{array}$ & $\begin{array}{c}50 \mathrm{bc} \\
(19-124)\end{array}$ & $\begin{array}{c}64 \mathrm{ab} \\
(8-160)\end{array}$ & $\begin{array}{c}45 b c \\
(6-128)\end{array}$ & $\begin{array}{c}40 c \\
(12-94)\end{array}$ \\
\hline & HSW (g) & $\begin{array}{c}29.5 \mathrm{ab} \\
(16.0-38.9)\end{array}$ & $\begin{array}{c}30.9 \mathrm{a} \\
(24.0-37.0)\end{array}$ & $\begin{array}{c}30.1 \mathrm{a} \\
(17.1-36.0)\end{array}$ & $\begin{array}{c}30.9 \mathrm{a} \\
(22.0-37.8)\end{array}$ & $\begin{array}{c}25.5 b \\
(16.0-33.9)\end{array}$ & $\begin{array}{c}25.9 b \\
(12.1-40.0)\end{array}$ & $\begin{array}{c}29.6 \mathrm{ab} \\
14.3-40.0)\end{array}$ \\
\hline & $\mathrm{FPH}(\mathrm{cm})$ & $\begin{array}{c}4 d \\
(2-7)\end{array}$ & $\begin{array}{c}7 d \\
(4-11)\end{array}$ & $\begin{array}{c}11 \mathrm{c} \\
(8-17)\end{array}$ & $\begin{array}{c}16 b \\
(7-25)\end{array}$ & $\begin{array}{c}21 \mathrm{a} \\
(8-31)\end{array}$ & $\begin{array}{c}21 \mathrm{a} \\
(9-31)\end{array}$ & $\begin{array}{c}22 a \\
(9-37)\end{array}$ \\
\hline & $\mathrm{PH}(\mathrm{cm})$ & $\begin{array}{c}52 \mathrm{~cd} \\
(26-89) \\
\end{array}$ & $\begin{array}{c}49 d \\
(27-73) \\
\end{array}$ & $\begin{array}{l}62 \mathrm{abcd} \\
(46-96)\end{array}$ & $\begin{array}{c}66 \mathrm{ab} \\
(29-101) \\
\end{array}$ & $\begin{array}{c}74 a \\
(26-105) \\
\end{array}$ & $\begin{array}{c}64 \mathrm{abc} \\
(29-95)\end{array}$ & $\begin{array}{c}56 \mathrm{bcd} \\
(22-92)\end{array}$ \\
\hline \multicolumn{2}{|c|}{ No. of samples } & 11 & 16 & 18 & 21 & 26 & 22 & 12 \\
\hline \multirow{5}{*}{$\begin{array}{l}\text { Pop II } \\
(\text { Uram } \times \\
\text { Milyang 257) }\end{array}$} & YP (g/plant) & $\begin{array}{c}48.3 a \\
(46-51)\end{array}$ & $\begin{array}{l}38.3 \mathrm{ab} \\
(4-96)\end{array}$ & $\begin{array}{l}26.1 \mathrm{bc} \\
(10-50)\end{array}$ & $\begin{array}{l}25.2 \mathrm{bc} \\
(2-72)\end{array}$ & $\begin{array}{l}15.2 \mathrm{c} \\
(2-28)\end{array}$ & $\begin{array}{l}18.3 \mathrm{c} \\
(6-38)\end{array}$ & $\begin{array}{l}15.1 \mathrm{c} \\
(2-30)\end{array}$ \\
\hline & NP & $\begin{array}{c}109 a \\
(103-114)\end{array}$ & $\begin{array}{c}110 \mathrm{a} \\
(17-227)\end{array}$ & $\begin{array}{c}78 \mathrm{ab} \\
(34-138)\end{array}$ & $\begin{array}{c}81 \mathrm{ab} \\
(18-157)\end{array}$ & $\begin{array}{c}58 b \\
(10-89)\end{array}$ & $\begin{array}{c}61 b \\
(27-96)\end{array}$ & $\begin{array}{c}46 b \\
(11-81)\end{array}$ \\
\hline & HSW (g) & $\begin{array}{c}23.8 \mathrm{a} \\
(22.0-25.5)\end{array}$ & $\begin{array}{c}20.1 \mathrm{ab} \\
(10.0-30.0)\end{array}$ & $\begin{array}{c}21.0 \mathrm{ab} \\
(12.0-26.0)\end{array}$ & $\begin{array}{c}18.7 \mathrm{ab} \\
(8.7-28.6)\end{array}$ & $\begin{array}{c}16.9 b \\
(9.6-26.5)\end{array}$ & $\begin{array}{c}18.7 \mathrm{ab} \\
(11.7-24.7)\end{array}$ & $\begin{array}{c}18.8 \mathrm{ab} \\
(9.5-28.0)\end{array}$ \\
\hline & $\mathrm{FPH}(\mathrm{cm})$ & $\begin{array}{c}5 f \\
(4-5)\end{array}$ & $\begin{array}{c}13 \mathrm{e} \\
(9-17)\end{array}$ & $\begin{array}{c}17 d \\
(11-24)\end{array}$ & $\begin{array}{c}22 c \\
(17-28)\end{array}$ & $\begin{array}{c}28 b \\
(22-35)\end{array}$ & $\begin{array}{c}30 \mathrm{~b} \\
(24-38)\end{array}$ & $\begin{array}{c}35 \mathrm{a} \\
(29-45)\end{array}$ \\
\hline & $\mathrm{PH}(\mathrm{cm})$ & $\begin{array}{c}70 b \\
(65-75)\end{array}$ & $\begin{array}{c}95 a \\
(77-126)\end{array}$ & $\begin{array}{c}92 \mathrm{a} \\
(60-122)\end{array}$ & $\begin{array}{c}93 a \\
(78-113)\end{array}$ & $\begin{array}{c}98 \mathrm{a} \\
(80-117)\end{array}$ & $\begin{array}{c}88 \mathrm{a} \\
(70-113)\end{array}$ & $\begin{array}{c}92 \mathrm{a} \\
(76-111)\end{array}$ \\
\hline \multicolumn{2}{|c|}{ No. of samples } & 2 & 15 & 15 & 15 & 15 & 16 & 10 \\
\hline
\end{tabular}

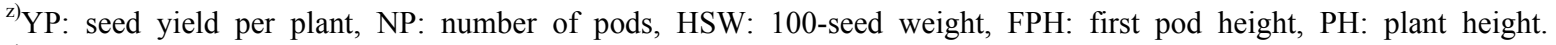
${ }^{\mathrm{y})}$ Within rows, means followed by the same letter are not significantly different according to DMRT at 0.05 level. ${ }^{\mathrm{x})}$ Value in parenthesis indicate the range of evaluated traits in each ratio of first pod height to plant height.
} 
Heritability for FPH of Pop I, Pop II, and Pop III was 51, 79, and $67 \%$, respectively. Mean heritability for FPH was $66 \%$. Heritability for plant height of Pop I, Pop II, and Pop III was 90,82 , and $73 \%$, respectively. Mean heritability for plant height was $81 \%$ and comparably higher than that of FPH. In correlation analysis, FPH showed positive and significant correlation with plant height $(r=0.61, P<0.001)$, number of nodes $(r=0.49, P<0.001)$ and stem thickness $(r=0.17$, $P<0.001)$ but showed negative correlation with the number of pods $(r=-0.47, P<0.001)$ (Table 5).

\section{The effect of ratio of FPH to PH on seed yield, number of pods and 100-seed weight in $F_{2}$ populations}

Mean and range data obtained from the samples in Pop I and Pop II are given in Table 6. The data suggests that the increased $\mathrm{FPH} / \mathrm{PH}$ affects number of pods per plant and yield negatively. When FPH/PH was more, the yield decreased significantly. In Pop I, the seed yield was significantly decreased from $32.0 \mathrm{~g}$ in $0.05-0.10$ ratio to 5.5 $\mathrm{g}$ in $0.31-0.35$. The number of pod that is a trait highly related to seed yield was also significantly decreased from 79 in $0.05-0.10$ ratio to 45 in 0.31-0.35. In Pop II, similar variation of evaluated traits was recognized. The seed yield was significantly decreased from $48.3 \mathrm{~g}$ in $0.05-0.10$ ratio to $0.26-0.30$ and the number of pods was also significantly decreased from 109 in 0.05-0.10 ratio to 58 in 0.26-0.30. The variation of one-hundred seed weight in Pop I and Pop II was not shown meaningful tendency relating to FPH/PH. FPH in Pop I and Pop II was increased, but variation of plant height was not relating to variation of $\mathrm{FPH} / \mathrm{PH}$.

\section{DISCUSSION}

Phenotypic variation for a quantitative trait is influenced by the genetic and environmental factors. FPH is a quantitative trait (Fig. 1) and affected by the environments, such as seeding date and planting distance. In this study, decrease in the FPH was observed with increased planting distance and delayed the seeding date. These results were similar with the studies reported by Ibrahim (2012a, $2012 b$ ). Furthermore, significant $\mathrm{D} \times \mathrm{S}$ and $\mathrm{G} \times \mathrm{S}$ interactions, like those reported by Ibrahim (2012a, 2012b) and
Karaaslan et al. (2012) were observed. However, in one of the study, Naglamu (2013) showed that $\mathrm{G} \times \mathrm{S}$ interactions were not significant in the genotypes they evaluated. It is evident from these results that genotypes may respond differently to the environments such as planting distance and seeding date. Thus, the genotypes, showing stable variation for FPH need to be identified and used as a breeding resource for different cultivation environments.

Heritability analyses in the segregating populations are conducted to estimate the genetic effects of FPH. Martin and Wilcox (1973) evaluated three $F_{2}$ populations for FPH and estimates of heritability were $63 \%$ (Beeson $\times$ L66-1085-1-270), 74\% (Amsoy71 × L66-1085-1-239) and 50\% (Wayne $\times$ L66-1085-1-251). Costa et al. (2008) also evaluated $57 \quad F_{2}$ and $F_{3}$ families derived from six populations, in which the estimates of broad sense heritability were $82 \%$ (BRSMG Renascença $\times$ BR-16), $48 \% \quad$ (MGBR95-20937 $\times$ IAC Foscarin31), 45\% (MGBR95-20937 × BR-16), 66\% (BRSMG Liderança $\times$ Embrapa-48), 43\% (BRSMG Liderança $\times$ IAC Foscarin31), and 95\% (BRSMG Renascença $\times$ Embrapa-48) for the respective crosses. When heritability is higher than $50 \%$, it means that phenotypic variation is more affected by genetic factors than environmental factors (Stansfield 2005). High heritability for FPH was observed in this study. This result show that $66 \%$ of the overall variation could be explained by genotypic differences among individuals in $F_{2}$ population. Therefore, selection for FPH in early generation like as $F_{2}$ population is possible and efficient for maintaining phenotype to the following generation (Costa et al. 2008).

The frequency distribution of FPH in three $\mathrm{F}_{2}$ populations (Pop I: Uram $\times$ Chamol, Pop II: Uram $\times$ Milyang 257 and Pop III: IT143195 $\times$ Uram) showed normal distribution in the $\mathrm{F}_{2}$ populations, indicating that $\mathrm{FPH}$ behave as a quantitative trait in these populations.

FPH was found to show positive correlation with plant height, number of nodes and stem thickness, but negative correlation with the number of pods. Similar correlations were observed by Oz et al. (2009), Ramteke et al. (2012), Ghodrati et al. (2013) and Pirdashti et al. (2010). Especially, the number of pods was negatively correlated with FPH. This result suggests that higher FPH may cause 
decrease in the number of pods and seed yield.

The number of pods is one of the most important traits determining seed yield (Oz et al. 2009). Previous studies indicated the positive correlation between seed yield and number of pods (Malik et al. 2006; Ramgiry et al. 1998). For this reason, it should be avoided to develop only a higher FPH cultivar without considering relationship between FPH and seed yield. Our results indicated that not only FPH but also the FPH/PH ratio is a significant factor that affect the seed yield (Table 6). It is important to understand that while the FPH should be higher than the height of the cutter in combine harvester, the FPH/PH ratio should be kept minimum. Ramteke et al. (2012) referred that FPH should be at least $12 \mathrm{~cm}$ for minimum yield loss with combine harvest. Stubble height was about $15 \mathrm{~cm}$ therefore, lower pods than this height should make yield loss (Son and Heo 2002).

Although the highest yield was achieved in the two populations when the $\mathrm{FPH} / \mathrm{PH}$ ratio was between 0.05-0.10, the FPH for the Pop I and Pop II was in the range 2-7 and 4-5, respectively. Therefore, it is difficult to select FPH around $15 \mathrm{~cm}$ for combine harvest in this ratio. However, when the FPH/PH ratio range was $0.16-0.25$, the seed yield per plant was 8-58 $\mathrm{g}$ with FPH ranged $4-17 \mathrm{~cm}$ in Pop I. In case of Pop II, when the FPH/PH ratio range was 0.11-0.20, the seed yield per plant was 4-96 g with FPH ranged 9-24 cm. These results indicated that soybean yield and FPH were different by cross combination and FPH/PH ratio range $0.16-0.25$ had proper range for FPH and seed yield in both population.

In conclusion, high FPH prevents harvesting losses, but seed yield in a plant could be decreased. Seed yield was found to reduce with increase in the FPH/PH ratio. The adequate $\mathrm{FPH} / \mathrm{PH}$ ratio for a plant was found to be $0.16-0.25$ in the present study. FPH is a trait which can be selected by phenotype in the field because genetic variation of FPH is higher than environmental variation. However, genetic information (e.g., QTLs and related genes) of FPH is not analyzed at this time. Knowledge of genetic background of agricultural trait is important for breeders. Therefore, further research for identifying detailed genetic information should be conducted in the future.

\section{ACKNOWLEDGEMENTS}

This research was supported by the National Institute of Crop Science (NICS), Rural Development Administration (RDA) of South Korea (No. PJ011225022017).

\section{REFERENCES}

Charles WS, Ellis L, Hires W. 1993. Measuring and reducing soybean harvesting losses. [Internet]. University of Missouri. [cited 2017 Feb 7]. Available from: http:// extension.missouri.edu/p/G1280.

Costa MM, Mauro AO, Helena S, Trevisoli U, Arriel NHC, Barbaro IM, et al. 2008. Heritability estimation in early generations of two-way crosses in soybeans. Bagantia Campinas. 67: 101-108.

Fehr WR, Caviness CE, Burmood DT, Pennington JS. 1971. Stage of development descriptions for soybeans, Glycine $\max ($ L.) Merrill. Crop Sci. 11: 929-931.

Ghodrati GR, Sekhavat R, Gholami A. 2013. Evaluation of correlations and path analysis of components seed yield in soybean. Int. J. Agric. 3: 795-800.

Holland JB, Nyquist WE. 2003. Estimating and interpreting heritability for plant breeding: an update. p.9-112. In: J. Janick (ed.). Plant breeding reviews. Willey \& Sons, Inc.

Ibrahim SE. 2012a, Agronomic studies on irrigated soybeans in central Sudan: I. Effect of plant spacing on grain yield and yield components. Int. J. of AgriScience. 2: 733-739.

Ibrahim SE. 2012b. Agronomic studies on irrigated soybeans in central Sudan: II. Effect of sowing date on grain yield and yield components. Int. J. of AgriScience. 2: 766-773.

Karaaslan D, Hakan M, Ekinci R, Boydak E. 2012. The impact of different seeding dates on seed yield of soybean. J. Anim. Plant Sci. 22: 175-182.

Ko JM, Han WY, Kim HT, Lee YH, Choi MS, Lee BW, et al. 2016. Soybean cultivar for soy-paste, 'Uram' with mechanization harvesting, large seed, disease resistance and high yield. Korean J. Breed. Sci. 48: 301-306.

Kowalczuk J. 1999. Pattern of seed losses and damage during soybean harvest with grain combine harvesters. Int. Agrophysics. 13: 103-107.

Lee CY, Choi MS, Yun HT, Lee BW, Chung YS, Kim RW, et al. 2015. Soybean [Glycine max (L.) Merrill]: importance as a crop and pedigree reconstruction of Korean varieties. 
Plant Breed. Biotech. 3: 179-196.

Mahmud I, Kramer HH. 1951. Segregating for yield, height, and maturity following a soybean cross. Agron. J. 43: 605-609.

Malik MFA, Qureshi AS, Ashraf M, Ghafoor A. 2006. Genetic variability of the main yield related characters in soybean. Int. J. Agric. Biol., 8: 815-819

Martin RJ, Wilcox JR. 1973. Heritability of lowest pod height in soybeans. Crop. Sci. 13: 201-203.

Ngalamu T, Ashraf M, Meseka S. 2013. Soybean (Glycine $\max$ L. Merrill) genotype and environment interaction effect on yield and other related traits. Am. J. Exp. Agric. 3: 977-987.

Oz M, Karasu FA, Goksoy AT, Turan ZM. 2009. Interrelationships of agronomical characteristics in soybean (Glycine $\max$ L. Merrill) grown in different environments. Int. J. Agric. Biol. 11: 85-88.

Pirdashti H, Motaghian A, Mohammad AB. 2010. Effects of organic amendments application on grain yield, leaf chlorophyll content and some morphological characteristics in soybean cultivars. J. Plant Nutr. 33: 485-495.

Ramgiry SR, Raha P, Tiwari VN. 1998. Genetic analysis of yield and quality attributes in soybean (Glycine $\max \mathrm{L}$. Merrill). Adv. Plant Sci. 11: 83-36.

Ramteke R, Singh DH, Murlidharan P. 2012. Selecting soybean (Glycine max L. Merrill) genotypes for insertion height of the lowest pod, the useful trait for combine harvester. Indian J. Agric. 82: 511-515.

Son CK, Heo CS. 2002. Selection soybean cultivars for mechanized harvest, p. 108-116. In: Research report. Gyeongsangbuk-do Agricultural Research \& Extension Services. Daegu.

Stansfield WD. 2005. Genetics: Theory and problems. 3rd ed. McGrw-Hill. NY.

Thompson JF, Blank SC. 2000. Harvest mechanization helps agriculture remain competitive. California Agriculture. 54: 51-56. 